\title{
PENGEMBANGAN BAHAN AJAR PROGRAM LINEAR BERBANTUAN LINDO SOFTWARE
}

\author{
Oleh: \\ 1) Rahmy Zulmaulida, ${ }^{2)}$ Edy Saputra \\ ${ }^{1,2)}$ Pendidikan Matematika Universitas Almuslim Peusangan Bireun \\ ${ }^{1}$ rahmyzulmaulida@gmail.com, ${ }^{2}$ edysaputra.esa@gmail.com
}

\begin{abstract}
ABSTRAK
Penelitian ini bertujuan untuk menelaah hasil belajar mahasiswa yang mendapat perkuliahan program linear dengan pengembangan bahan ajar berbantuan lindo software. Permasalahan dalam program linier adalah permasalahan yang berhubungan dengan pencapaian fungsi sasaran atau masalah optimasi, yaitu yang bertujuan memecahkan masalah dengan cara terbaik, sesuai dengan prinsip ekonomi yang berorientasikan untuk senantiasa menekan (meminimalkan) pengeluaran untuk mendapatkan hasil yang maksimal. Bahan ajar adalah segala bentuk yang digunakan untuk membantu guru/ instruktur dalam melaksanakan kegiatan belajar mengajar di kelas. Bahan yang dimaksud bisa berupa bahan tertulis maupun bahan tidak tertulis. Bahan ajar merupakan informasi, alat dan teks yang diperlukan guru/instruktur untuk perencanaan dan penelaahan implementasi pembelajaran. Lindo (Linear Interaktive Discrete Optimizer) adalah software yang dapat digunakan untuk mencari penyelesaian dari masalah pemrograman linear. Dengan menggunakan software ini memungkinkan perhitungan masalah pemrograman linear dengan $n$ variabel. Prinsip kerja utama Lindo adalah memasukkan data, menyelesaikan, serta menaksirkan kebenaran dan kelayakan data berdasarkan penyelesaiannya.
\end{abstract}

Kata Kunci : Bahan Ajar, Program Linear, Lindo Software

\begin{abstract}
The aim of this rsearch is to analyse the result of students' achievement in the lesson of linear program with the developing of teaching material with the assistance of software lindo.The problem in linear prgram is the problem which is related to the reaching of the target function or the problem of optimation that is aimed to solve the problem by using the best way which is suitable with ecomical principle that is oriented to maximalize the incomes but minimize the outcomes. Teaching material is all things that is used to help teachers/ instructors in teaching and learning process in the classroom. It can be both written and unwritten materials. It is such an information, things $\mathrm{n}$ texts those are needed by teachers/ instr to do such a planning $\mathrm{n}$ analyzing toward teaching implementation.Lindo is a software that can be used to find out the solving of linear program problems. By using this software, it is possible to count the problem of linear problem with $\mathrm{n}$ variable. The main principle of lindo is by inputting the data, solving the data, $\mathrm{n}$ estimating the truth $\mathrm{n}$ yhe properity of the data based on its' discussion result.
\end{abstract}

Keywords: Teaching Material, Linear Program, Lindo Software 


\section{PENDAHULUAN}

\subsection{Latar Belakang}

Pendidikan dalam pengertian pengajaran di sekolah adalah suatu usaha yang bersifat sadar, sistematis, dan terarah agar peserta didik secara aktif mengembangkan potensi dirinya untuk memiliki kekuatan spiritual keagamaan, pengendalian diri, kepribadian, kecerdasan, akhlaq mulia, serta keterampilan yang diperlukan dirinya, masyarakat, bangsa dan negara (UU Sisdiknas 2003:5).

Mulyasa (2008:3) mengungkapkan bahwa pendidikan dapat dilihat dan dirasakan secara langsung dalam perkembangan serta kehidupan masyarakat, kehidupan kelompok, dan kehidupan setiap individu. Pendidikan memegang peranan yang sangat menentukan bagi perkembangan dan perwujudan diri siswa. Hal ini karena pendidikan menyediakan lingkungan yang memungkinkan siswa untuk mengembangkan kemampuannya secara optimal. Melalui kemampuan itulah siswa dapat mewujudkan dirinya dan berfungsi sepenuhnya sesuai dengan kebutuhan pribadi dan masyarakat.

Pesatnya perkembangan ilmu pengetahuan dan teknologi membawa pengaruh yang besar terhadap perkembangan pola pikir masyarakat. Program pendidikan yang ada pada saat ini diharapkan mampu menyediakan sumber daya manusia yang mampu menjawab dan memecahkan masalah sesuai dengan tuntutan zaman. Untuk memenuhi kebutuhan tersebut, dapat diwujudkan dalam bentuk pembaharuan dunia pendidikan serta penekanan-penekanan pada hal-hal yang masih kurang diminati siswa.

Matematika merupakan ilmu yang universal yang mendasari perkembangan teknologi modern. Matematika juga mempunyai peran penting dalam berbagai disiplin ilmu dan memajukan daya pikir manusia. Mengembangkan matematika dapat diperoleh melalui pembelajaran matematika yang bertujuan untuk memajukan daya pikir manusia secara aktif. UNESCO yang dikutip oleh Sumarmo (2006:2) menyatakan bahwa Pembelajaran matematika mengacu pada prinsip siswa belajar aktif dan "learning how to learn" yang rinciannya termuat dalam empat pilar pendidikan yaitu: (1) learning to know, (2) learning to do, (3) learning to be, dan (4) learning to live together.

Bell (1987) menyatakan bahwa matematika merupakan ratu dan pelayan ilmu pengetahuan. Dari kedudukan matematika sebagai ratu ilmu pengetahuan, tersirat bahwa matematika itu sebagai suatu ilmu, berfungsi untuk melayani ilmu pengetahuan lain. Dengan perkataan lain, matematika tumbuh dan berkembang untuk dirinya sendiri sebagai suatu ilmu, juga untuk melayani kebutuhan ilmu pengetahuan dalam pengembangan dan operasionalnya (Suherman, dkk, 2003). Hal inilah yang menyebabkan matematika dijadikan mata pelajaran wajib di setiap 
jenjang pendidikan formal. Matematika diajarkan mulai dari tingkat dasar sampai tingkat perguruan tinggi.

Pada perguruan tinggi, khususnya pada Program Studi Pendidikan Matematika FKIP Universitas Almuslim, salah satu mata kuliah yang diampu ialah mata kuliah program linear. Mata kuliah yang mempunyai prasyarat aljabar elementer dan aljabar linear ini dapat diikuti oleh mahasiswa pada semester III dengan bobot 2 sks. (Jabar, 2011:2) mengungkapkan Program Linier merupakan metode matematik dalam mengalokasikan sumberdaya yang langka untuk mencapai tujuan tunggal seperti memaksimumkan keuntungan atau meminimumkan biaya. Program Linier banyak diterapkan dalam membantu menyelesaikan masalah ekonomi, indutri, militer, sosial dan lain-lain. Permasalahan dalam program linier adalah permasalahan yang berhubungan dengan pencapaian fungsi sasaran atau masalah optimasi, yaitu yang bertujuan memecahkan masalah dengan cara terbaik, sesuai dengan prinsip ekonomi yang berorientasikan untuk senantiasa menekan (meminimalkan) pengeluaran untuk mendapatkan hasil yang maksimal.

Pengalaman peneliti mengampu mata kuliah program linear pada semester sebelumnya, sebagian besar mahasiswa semester III memperoleh hasil belajar yang rendah pada mata kuliah program linear. Rendahnya hasil belajar ini dimungkinkan karena pada perkuliahan program linear, mahasiswa banyak menghadapi soal cerita. Soal cerita ini berkenaan dengan masalah-masalah yang dapat dijumpai oleh mahasiswa dalam kehidupan sehari-hari. Dalam menyelesaikan soal cerita program linear, mahasiswa dituntut untuk memiliki kemampuan memahami masalah, membuat model matematika, dan menyelesaikan masalah sesuai dengan apa yang ditanyakan. Rendahnya kemampuan-kemampuan tersebut dimungkinkan akan menyebabkan rendahnya hasil belajar mahasiswa pada mata kuliah program linear. Hal ini sependapat dengan Natawijaya (Rusmini, 2007:3), bahwa banyak mahasiswa yang mengalami kesulitan dalam mencapai hasil belajar sebagaimana yang diharapkan, seperti :

1. Mahasiswa jarang bertanya, karena kebanyakan tidak tahu dan tidak mengerti apa yang ditanyakan.

2. Mahasiswa jarang memberikan tanggapan, karena belum mampu menjelaskan ide-ide matematika dengan baik.

3. Beberapa mahasiswa mampu menyelesaikan soal matematika, tetapi kurang memahami apa yang terkandung di dalam soal tersebut (tidak meaningful).

4. Masih banyak mahasiswa yang tidak mampu membuat suatu kesimpulan dari materi yang telah dipelajari.

Salah satu cara untuk meningkatkan komunikasi matematis belajar mahasiswa terhadap mata kuliah program linear adalah dengan menggunakan teknologi. Teknologi merupakan suatu model inovasi yang dapat dipilih dalam proses belajar mengajar. Menurut Paul W. Devore (Chairani, 2011: 1), teknologi adalah ilmu terapan yang telah dikembangkan lebih lanjut dan meliputi perangkat keras dan 
perangkat lunak yang merupakan manivestasi atas kekuasaan terhadap alam, manusia dan kebudayaannya. Teknologi adalah kemampuan menerapkan suatu pengetahuan dan kepandaian membuat sesuatu yang berkenaan dengan suatu produk, yang berhubungan dengan seni, yang berlandaskan pengetahuan ilmu eksakta bersandarkan pada aplikasi dan implikasi pengetahuan itu sendiri.

Teknologi yang merupakan aplikasi kemajuan ilmu pengetahuan yang membawa dunia pendidikan untuk menyesuaikannya. Strategi pembelajaran harus berorientasi pada kebutuhan teknologi masa kini, artinya setiap materi yang sudah dirancang dalam jabaran kurikulum dicarikan link dengan masalah kontekstual dan teknologi, adalah kegunaan materi yang diajarkan sekarang di masa yang akan datang. Dalam menghadapi dan menyikapi kurikulum yang berbasis kompetensi maka diperlukan kemampuan yang memadai di bidang ilmu pengetahuan dan teknologi, terutama di bidang komputer. Perkembangan teknologi sekarang ini menuntut penggunaan komputer yang lebih bervariatif dan efektif, termasuk didalamnya penggunaan aplikasi komputer dalam proses pembelajaran di sekolah sebagai media pembelajaran atau media pendidikan, diantaranya dengan menggunakan multimedia pembelajaran dengan komputer.

Karakteristik Matematika yang memiliki objek kajian abstrak dan membutuhkan daya berpikir logis pada dasarnya adalah pemicu awal munculnya teknologi komputer yang berasal dari mesin hitung, kalkulator. Jauh sebelum munculnya istilah teknologi, pembelajaran matematika sudah memanfaatkan kalkulator sebagai media pembelajaran. sebagaimana diungkapkan oleh Yaya S.Kusumah dalam pidato pengukuhan guru besarnya bahwa sudah saatnya komputer diberdayakan untuk kepentingan pembelajaran matematika; bukan saja menyelesaikan masalah-masalah matematika, tetapi juga memberi bantuan tentang cara penyampaian materi matematika itu sendiri dengan cara-cara yang menarik, menantang, dan memperhatikan perbedaan individual siswa.

Pada dasarnya pemanfaatan teknologi dalam pendidikan matematika sangatlah luas, baik sebagai media pembelajaran di dalam kelas maupun sebagai media belajar mandiri. Pembelajaran di dalam kelas dapat dilakukan dengan memanfaatkan media visual atau audio visual sebagai bantuan membawa konteks ke dalam kelas untuk memperlihatkan pada siswa aplikasi konsep-konsep matematika tanpa harus melihat langsung, pembelajaran ini dapat diterapkan pada siswa tingkat Menengah Pertama yang sesuai dengan teori perkembangan mental Piaget berada pada tahap operasi formal sehingga mulai dapat berpikir abstrak pada tahap-tahap awal. Selain itu pada pembelajaran matematika pada jenjang yang lebih tinggi, ketika memasuki konsepkonsep seperti kalkulus, geometri, Numerik, diskrit, aljabar serta peluang dan statistic pemanfaatan software-software seperti, Mathematica, Maple, Matlab, fortran, Basica, Geometer Skechtpad, Cabri, Minitab, SPSS, Microsoft Math, Lindo dan lain-lain berdasarkan hasil-hasil penelitian menunjukkan dapat meningkatkan kemampuan berpikir tingkat tinggi serta minat belajar matematika. 
Jika melihat karakteristik matematika, beberapa materi seperti Metode Numerik ataupun program linear pemanfaatan media komputer sangat perlu karena pada kasus-kasus yang lebih kompleks perhitungan yang diilakukan manual sangat tidak efektif dan efisien. Hal ini peneliti menawarkan sebuah program berbasis IT yang dapat digunakan pada mata kuliah program linear yaitu Lindo Software.

Lindo (Linear Interaktive Discrete Optimizer) adalah software yang dapat digunakan untuk mencari penyelesaian dari masalah pemrograman linear. Dengan menggunakan software ini memungkinkan perhitungan masalah pemrograman linear dengan $n$ variabel. Prinsip kerja utama Lindo adalah memasukkan data, menyelesaikan, serta menaksirkan kebenaran dan kelayakan data berdasarkan penyelesaiannya. Menurut Linus Scharge (Atini:2013), Perhitungan yang digunakan pada Lindo pada dasarnya menggunakan metode simpleks. Sedangkan untuk menyelesaikan masalah pemrograman linear integer nol-satu software Lindo menggunakan Metode Branch and Bound (metode Cabang dan Batas) menurut Mark Wiley (2010). Untuk menentukan nilai optimal dengan menggunakan Lindo diperlukan beberapa tahapan yaitu: (1) Menentukan model matematika berdasarkan data real; (2) Menentukan formulasi program untuk Lindo; (3) Membaca hasil report yang dihasilkan oleh Lindo.

Hermanto (2010:2) mengungkapkan Jika hanya menggunakan program linier secara manual atau dengan menggunakan metode simpleks akan lebih sulit dan memakan waktu lebih lama karena membutuhkan ketelitian dan ketekunan yang tinggi. Untuk itu sangatlah tepat jika masalah dalam program linier dengan berbagai kejadian masalah optimasi ataupun segala permasalahan optimasi dalam dunia nyata di cari penyelesaiannya dengan Lindo

Dari uraian masalah dan pendapat-pendapat yang telah diungkapkan di atas, penulis tertarik untuk melakukan penelitian terkait dengan "Pengembangan Bahan ajar Program Linear Berbantuan Lindo Software”.

\subsection{Rumusan Masalah}

Berdasarkan latar belakang masalah yang telah diuraikan diatas, permasalahan dalam penelitian ini dirumuskan sebagai berikut: (1) Bagaimanakah hasil belajar mahasiswa terhadap pengembangan bahan ajar program linear berbantu lindo software? (2) Bagaimana bentuk formula penyelesaian model matematika dari suatu masalah optimasi dengan Lindo?

\subsection{Manfaat Penelitian}

Manfaat dilaksanakannya penelitian ini adalah: (1) Menjawab keingintahuan bagi peneliti serta memberikan informasi mengenai hasil belajar mahasiswa yang mendapat perkuliahan dengan pengembangan bahan ajar program linear berbantuan 
Lindo Software; (2) Penelitian ini memberikan motivasi kepada pendidik matematika untuk memanfaatkan kemajuan teknologi dan sarana yang telah tersedia dalam bentuk media pembelajaran berbasis komputer berupa program Lindo Software; (3) Memberikan informasi mengenai sejauh mana belajar program linear berbantuan Lindo Software berpengaruh terhadap hasil belajar mahasiswa.

\section{KONSEP PENGEMBANGAN DAN TINJAUAN TEORITIK}

\subsection{Bahan Ajar}

Bahan ajar adalah segala bentuk bahan yang digunakan untuk membantu guru/ instruktur dalam melaksanakan kegiatan belajar mengajar di kelas. Bahan yang dimaksud bisa berupa bahan tertulis maupun bahan tidak tertulis. Bahan ajar merupakan informasi, alat dan teks yang diperlukan guru/instruktur untuk perencanaan dan penelaahan implementasi pembelajaran (Dikti).

Purnomo (2011:1) mengungkapkan bahwa Keberhasilan pembelajaran, dipengaruhi banyak faktor, antara lain model pembelajaran, strategi pembelajaran, media pembelajaran, dan juga bahan ajar atau materi pelajaran. Bahan ajar yang disusun mempunyai prisip relevansi, konsistensi dan kecukupan, sehingga masih memberi ruang siswa untuk mengembangkan penalaranya. Bahan ajar ( Instructional materials ) adalah pengetahuan, ketrampilan, dan sikap yang harus dipelajari siswa dalam rangka mencapai standar kopetensi yang telah ditentukan. Secara terperinci , jenis-jenis materi pembelajaran terdiri atas pengetahuan ( fakta, konsep, prinsip , prosedur), ketrampilan, dan sikap atau nilai.

Bahan ajar dapat disajikan dalam bentuk : a) Bahan cetak, seperti: hand out, buku, modul, lembar kerja siswa, brosur, leaflet, wallchart; b)Audio , seperti: radio, kaset, $\mathrm{CD}$ audio, PH; c) Audio visual, seperti : video/film, VCD; d)Visual, seperti: foto, gambar, model / maket; e) multi media, seperti: CD interaktif, computer based , Internet. Secara umum cakupan bahan ajar meliputi: a) Judul, Mata pembelajaran, Standar kompetensi, kompetensi dasar, indikator, tempat; b) Petujuk pembelajaran( petujuk siswa/guru); c) Tujuan yang akan dicapai; d) Informasi pendukung; e) Latihan - latihan; f) Petujuk kerja; g) Penilaian.

Pemilihan materi pembelajaran (bahan ajar) hendaknya mempertimbangkan prinsip relevansi, konsistensi, dan kecukupan. Prisip relevansi, artinya materi pembelajaran yang dipilih memiliki relevansi (keterkaiatan) dengan pencapaian standar kompetensi dan kompetenasi dasar; Prinsip konsistensi artinya adanya keajegan antara bahan ajar dengan kompetensi dasar yang harus dikuasai siswa,misalnya , kompetensi dasar yang direncanakan empat macam, maka bahan ajar yang harus diaiarkan harus meliputi empat macam; Prisip kecukupan artinya materi yag diajarkan hendaknya cukup memadai dalam membantu siswa menguasai kompetensi 
dasar yang ditentukan, materi pembelajaran tidak terlalu sedikit, dan tidak terlalu banyak.

\subsection{Teknologi Informasi Komputer dalam Aktivitas Pendidikan Matematika}

ICT (Information Communication and Technology) adalah sistem atau teknologi yang dapat mereduksi batasan ruang dan waktu untuk mengambil, memindahkan, menganalisis, menyajikan, menyimpan dan menyampaikan data menjadi sebuah informasi. Pemahaman yang lebih umum istilah tersebut mengarah pada perkembangan teknologi komputer dan telekomunikasi/multimedia (dalam berbagai bentuknya), yang telah memiliki berbagai kemampuan sebagai pengolah data/informasi, alat kontrol, alat komunikasi, media pendidikan, hiburan dan lainya. Dari definisi ICT dan teknologi kunci dalam Domain TI jelas sekali bahwa teknologi informasi tidak bisa dilepaskan dengan teknologi komputer dan telekomunikasi.

Kehadiran TIK dalam pendidikan bisa dimaknai dalam tiga paradigma, yaitu (1) TIK sebagai alat atau berupa produk teknologi yang bisa digunakan dalam pendidikan, (2) TIK sebagai konten atau sebagai bagian dari materi yang bisa dijadikan isi dalam pendidikan, dan (3) TIK sebagai program aplikasi atau alat bantu untuk manajemen pendidikan yang efektif dan efisien. Ketiga paradigma tersebut disinergikan dalam sebuah kerangka sumberdaya TIK yang secara khusus diposisikan dan diarahkan untuk mencapai visi dan misi pendidikan di Indonesia. Di era globalisasi pendidikan, disadari ataupun tidak, tantangan dunia pendidikan ke depan akan lebih berat. Oleh karena itu, optimalisasi TIK menjadi salah satu alternatif solusi dalam menopang dan menggerakkan dunia pendidikan di kancah persaingan global.

Dalam dunia pendidikan di Indonesia, ada beberapa alasan problematik yang melatarbelakangi pentingnya pemanfaatan TIK, terutama dalam (1) meningkatkan mutu pendidikan di semua jenjang, (2) mengatasi kesenjangan layanan pendidikan akibat kondisi geografis yang mana jika diabaikan akan menimbulkan disparitas mutu layanan, dan (3) perubahan sosio-budaya masyarakat yang bergerak dinamis, dan (4) memupuk rasa nasionalisme untuk menjaga kesatuan dan persatuan bangsa.

Information Communication and Technologi (ICT) telah merambah dalam setiap bidang kehidupan manusia, termasuk dalam dunia pendidikan. Peranan ICT dalam dunia pendidikan sangatlah besar, tidak hanya dikalangan perguruan tinggi semata namun juga pada pendidikan anak usia dini.

Karakteristik Matematika yang memiliki objek kajian abstrak dan membutuhkan daya berpikir logis pada dasarnya adalah pemicu awal munculnya teknologi komputer yang berasal dari mesin hitung, kalkulator. Jauh sebelum munculnya istilah teknologi, pembelajaran matematika sudah memanfaatkan kalkulator sebagai media pembelajaran. sebagaimana diungkapkan oleh Yaya S.Kusumah dalam pidato 
pengukuhan guru besarnya bahwa sudah saatnya komputer diberdayakan untuk kepentingan pembelajaran matematika; bukan saja menyelesaikan masalah-masalah matematika, tetapi juga memberi bantuan tentang cara penyampaian materi matematika itu sendiri dengan cara-cara yang menarik, menantang, dan memperhatikan perbedaan individual siswa. Hal ini juga diperkuat dengan pendapat Glass (yang diungkapkan Yaya S. Kusumah dalam Perkuliahan Teknologi Informasi Komputer) bahwa Banyak sekali kontribusi nyata yang dapat dipersembahkan komputer bagi kemajuan pendidikan, khususnya pembelajaran matematika. Komputer dapat dimanfaatkan untuk mengatasi perbedaan invidual siswa; mengajarkan konsep; melaksanakan perhitungan dan menstimulir belajar siswa

Pada dasarnya pemanfaatan teknologi dalam pendidikan matematika sangatlah luas, baik sebagai media pembelajaran di dalam kelas maupun sebagai media belajar mandiri. Pembelajaran di dalam kelas dapat dilakukan dengan memanfaatkan media visual atau audio visual sebagai bantuan membawa konteks ke dalam kelas untuk memperlihatkan pada siswa aplikasi konsep-konsep matematika tanpa harus melihat langsung, pembelajaran ini dapat diterapkan pada siswa tingkat Menengah Pertama yang sesuai dengan teori perkembangan mental Piaget berada pada tahap operasi formal sehingga mulai dapat berpikir abstrak pada tahap-tahap awal. Selain itu pada pembelajaran matematika pada jenjang yang lebih tinggi, ketika memasuki konsepkonsep seperti kalkulus, geometri, Numerik, diskrit, aljabar serta peluang dan statistic pemanfaatan software-software seperti, Mathematica, Maple, Matlab, fortran, Basica, Geometer Skechtpad, Cabri, Minitab, SPSS, Microsoft Math, Lindo dan lain-lain berdasarkan hasil-hasil penelitian menunjukkan dapat meningkatkan kemampuan berpikir tingkat tinggi serta minat belajar matematika.

Keunggulan-keunggulan pemanfaatan teknologi dalam dunia pendidikan khusunya pendidikan matematika, yaitu:

a. Kesabaran yang tiada batas, tidak terkait dengan perasaan seperti lazimnya manusia;

b. Mampu memotivasi siswa dengan pujian yang dirancang khusus;

c. Memberi kesempatan bereksperimen tanpa dihantui kekuatiran akan kerusakan yang bisa terjadi;

d. Tidak diskriminatif;

e. Memberi siswa ketrampilan yang berharga untuk masa depannya,

f. Mempercepat proses perhitungan yang secara manual sangat lama waktu penyelesaiannya, atau bahkan tidak mungkin sama sekali

(Wepner, 1990; Bialo dan Sivin, 1990; Braun, 1990, Robertson, et al. , 1987).

\subsection{Lindo Software dan Penerapannya pada Mata Kuliah Program Linear}

Lindo (Linear Interaktive Discrete Optimizer) adalah software yang dapat digunakan untuk mencari penyelesaian dari masalah pemrograman linear. Dengan menggunakan software ini memungkinkan perhitungan masalah pemrograman linear 
dengan $\mathrm{n}$ variabel. Prinsip kerja utama Lindo adalah memasukkan data, menyelesaikan, serta menaksirkan kebenaran dan kelayakan data berdasarkan penyelesaiannya. Menurut Linus Scharge (Atini:2013), Perhitungan yang digunakan pada Lindo pada dasarnya menggunakan metode simpleks. Sedangkan untuk menyelesaikan masalah pemrograman linear integer nol-satu software Lindo menggunakan Metode Branch and Bound (metode Cabang dan Batas) menurut Mark Wiley (2010). Untuk menentukan nilai optimal dengan menggunakan Lindo diperlukan beberapa tahapan yaitu: (1) Menentukan model matematika berdasarkan data real; (2) Menentukan formulasi program untuk Lindo; (3) Membaca hasil report yang dihasilkan oleh Lindo.

Hermanto (2010:2) mengungkapkan Jika hanya menggunakan program linier secara manual atau dengan menggunakan metode simpleks akan lebih sulit dan memakan waktu lebih lama karena membutuhkan ketelitian dan ketekunan yang tinggi. Untuk itu sangatlah tepat jika masalah dalam program linier dengan berbagai kejadian masalah optimasi ataupun segala permasalahan optimasi dalam dunia nyata di cari penyelesaiannya dengan Lindo.

Untuk menentukan nilai optimal dengan menggunakan Lindo diperlukan beberapa tahapan yaitu:

a. Menentukan model matematika berdasarkan data real

b. Menentukan formulasi program untuk Lindo

c. Membaca hasil report yang dihasilkan oleh Lindo.

Perintah yang biasa digunakan untuk menjalankan program Lindo adalah:

\begin{tabular}{|c|c|c|}
\hline 1. & MAX & digunakan untuk memulai data dalam masalah maksimasi; \\
\hline 2. & MDT & digunakan untuk memulai data dalam masalah minimasi; \\
\hline 3. & END & digunakan untuk mengakhiri data; \\
\hline 4. & GO & digunakan untuk pemecahan dan penyelesaian masalah; \\
\hline 5. & LOOK & digunakan untuk mencetak bagian yang dipilih dari data yang ada; \\
\hline 6. & GDN & digunakan untuk variabel keputusan agar bernilai bulat; \\
\hline 7. & TNE & digunakan untuk menentukan solusi dari masalah biner; \\
\hline 8. & TNT & sama dengan ПNTE; \\
\hline 9. & SUB & digunakan untuk membatasi nilai maksimumnya; \\
\hline 10. & SLB & digunakan untuk membatasi nilai minimumnya; \\
\hline 11. & FREE & digunakan agar solusinya berupa bilangan real. \\
\hline
\end{tabular}

Kegunaan utama dari program Lindo adalah untuk mencari penyelesaian dari masalah linier dengan cepat dengan memasukan data yang berupa rumusan dalam bentuk linier. Lindo memberikan banyak manfaat dan kemudahan dalam 
memecahkan masalah optimasi dan minimasi. Berikut ini cara memulai menggunakan program Lindo adalah dengan membuka file Lindo kemudian klik dua kali pada Lindow32, tunggu sampai muncul dialog lalu klik OK, Lindo siap dioperasikan.

\section{a. Halaman Awal Lindo Software}

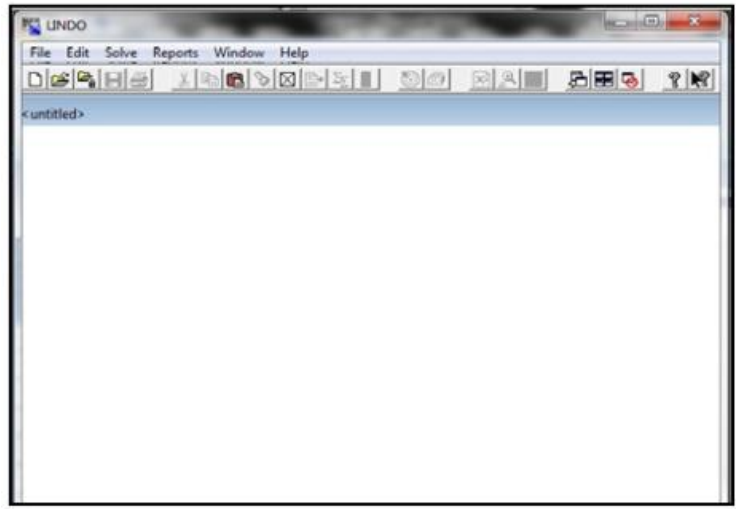

Gambar 1. Menu Untitled Baru

Pada layar akan muncul untitled baru yang siap untuk tempat mengetikkan formasi
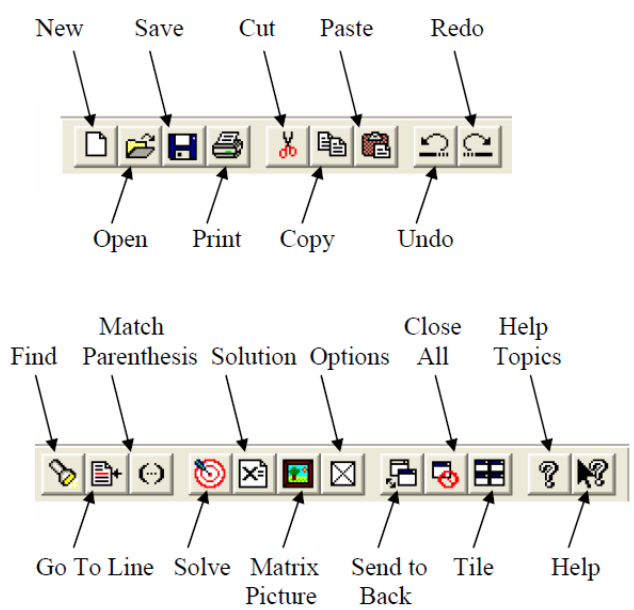

Gambar 2. Toolbar View Lindo Software

\section{b. Model Lindo Software}

Model Lindo minimal memiliki tiga syarat:

1) Memerlukan fungsi objektif;

2) variabel;

3) batasan (fungsi kendala). 
Untuk syarat pertama fungsi objektif, bisa dikatakan tujuan. Tujuan disini memiliki dua jenis tujuan yaitu maksimasi (MAX) dan minimasi (MIN). Kata pertama untuk mengawali pengetikan formula pada Lindo adalah MAX atau MIN. Formula yang diketikan ke dalam untitled (papan editor pada Lindo) setelah MAX atau MIN disebut fungsi tujuan. Secara umum dapat dituliskan sebagai berikut.

\section{Fungsi tujuan model matematika}

Min/Maks Z $=\mathrm{C} 1 \mathrm{X} 1+\mathrm{C} 2 \mathrm{X} 2+\ldots+\mathrm{CnXn}$

Diketikkan ke dalam untitled menjadi

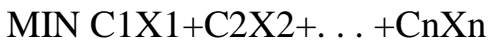

atau

MAX C1X1+C2X2+...+CnXn

Untuk syarat kedua adalah variabel. Variabel ini sangat penting, Lindo tidak dapat dijalankan tanpa memasukkan variabel dalam formula. Untuk syarat ketiga setelah fungsi objektif dan variabel selanjutnya adalah batasan Dalam kenyataannya variabel tersebut pasti memiliki batasan, batasan itu misalnya keterbatasan bahan, waktu, jumlah pekerja, biaya operasional. Setelah fungsi objektif diketikkan selanjutnya diketikkan Subject to atau ST untuk mengawali pengetikan batasan dan pada baris berikutnya baru diketikkan batasan yang ada diakhir batasan kita akhiri dengan kata END. Secara umum dapat dituliskan sebagai berikut.

\section{Fungsi Kendala}

$\mathrm{a} 11 \mathrm{X} 1+\mathrm{a} 12 \mathrm{X} 2+\ldots+\mathrm{C} 1 \mathrm{nXn} \leq \mathrm{b} 1$

$\mathrm{a} 11 \mathrm{X} 1+\mathrm{a} 22 \mathrm{X} 2+\ldots+\mathrm{C} 2 \mathrm{nXn} \leq \mathrm{b} 2$

$\mathrm{am} 1 \mathrm{X} 1+\mathrm{am} 2 \mathrm{X} 2+\ldots+\mathrm{CmnXn} \leq \mathrm{bm}$

$\mathrm{X} 1, \mathrm{X} 2 \ldots, \mathrm{Xn} \geq 0$

untuk pengetikkan fungsi kendala ke dalam untitled adalah sebagai berikut.

SUBJECT TO

a11X1+a12X2+. . +C1nXn $<=$ b1

$\mathrm{a} 11 \mathrm{X} 1+\mathrm{a} 22 \mathrm{X} 2+\ldots+\mathrm{C} 2 \mathrm{nXn}<=\mathrm{b} 2$

$\mathrm{am} 1 \mathrm{X} 1+\mathrm{am} 2 \mathrm{X} 2+\ldots+\mathrm{CmnXn}<=\mathrm{bm}$

$\mathrm{X} 1>=0$

$\mathrm{X} 2>=0$

$\mathrm{Xn}>=0$

END 


\section{Contoh :}

Akan diselesaikan model pemrograman linear integer berikut dengan menggunakan software Lindo

$\operatorname{Max} Z=100 \times 1+60 \times 2+70 \times 3+15 \times 4+15 \times 5$

Dengan fungsi kendala

$52 \times 1+23 \times 2+35 \times 3+15 \times 4+7 \times 5 \leq 60$

$\mathrm{xi}=$ for $\mathrm{i}=1,2, \ldots, 5$

\section{c. Formulasi pada Lindo Software}

formula pada contoh di atas dapat diketikan dengan:

MAX 100X1 + 60X2 +70X3 + 15X4 + 15X5

SUBJECT TO

$$
52 \mathrm{X} 1+32 \mathrm{X} 2+35 \mathrm{X} 3+15 \mathrm{X} 4+7 \mathrm{X} 5<=60
$$

END
INTE X1
INTE X2
INTE X3
INTE X4
INTE X5

Keseluruhan formulasi yang dapat diketikkan ke dalam untitled Lindo seperti pada gambar berikut:

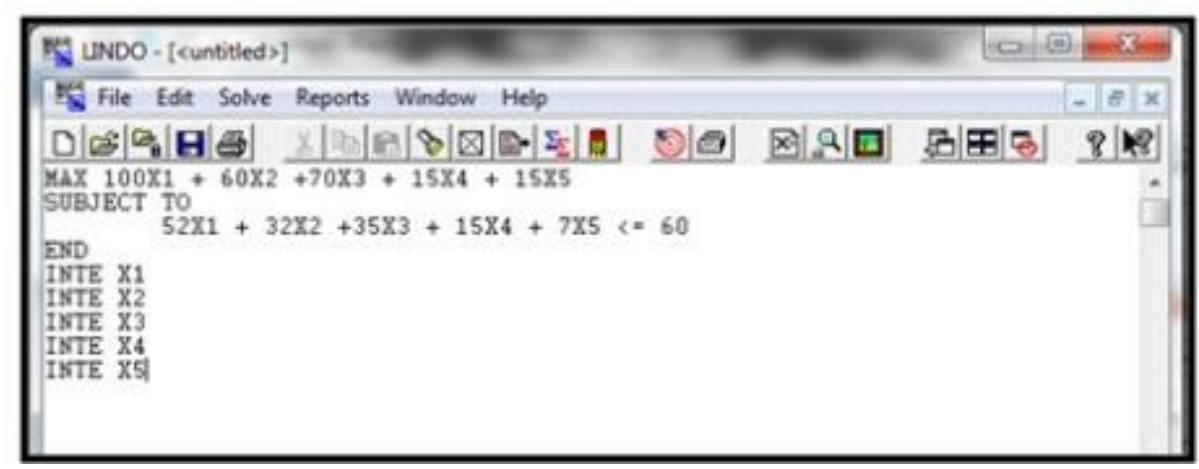

Gambar 3. Formulasi pada Lindo Software

Setelah formula diketikkan siap dicari solusinya dengan memilih perintah solve atau mengklik tombol solve pada toolbar. Lindo akan mengkompil (mengoreksi kesalahan) pada formula terlebih dahulu. Jika terjadi kesalahan dalam pengetikan (tidak dapat dibaca oleh komputer) akan muncul kotak dialog dan kursor akan menunjukkan pada baris yang salah. 


\section{d. Menu Solve}

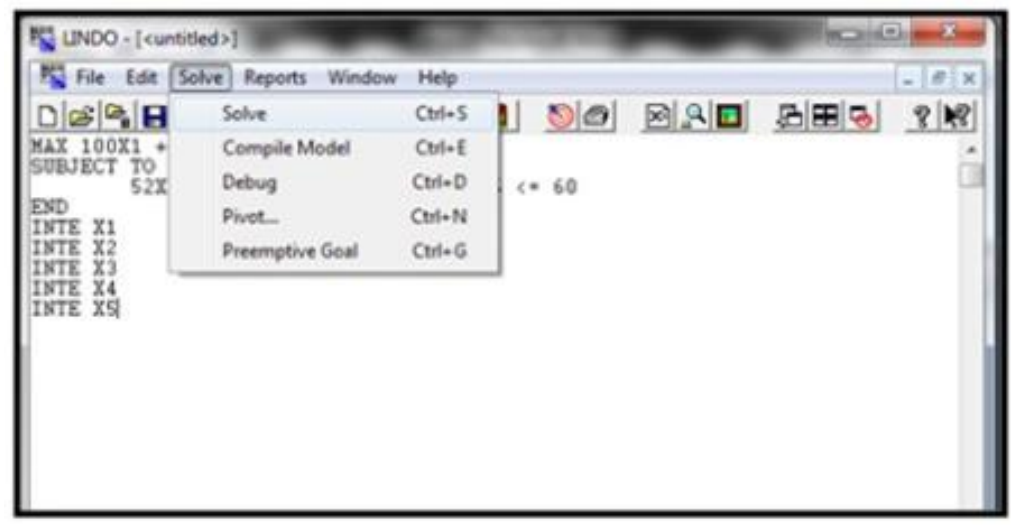

Gambar 4. Menu Solve pada Lindo Software

Menu solve digunakan untuk menampilkan hasil secara lengkap dengan beberapa pilihan berikut:

1) Solve-Solve, digunakan untuk menampilkan hasil optimasi dari data pada papan editor dan secara lengkap. Pada tampilan hasil mencangkup nilai variabel keputusan serta nilai dual price-nya. Pada nilai peubah keputusan ditampilkan pula nilai peubah keputusan yang nol. Perbedaannya dengan Report Solusion adalah pada Report Solusion kadang-kadang jawabannya tidak optimal interasinya, sehingga pada Solve-Solve jawaban yang ditampilkan bernilai optimal. Report Solution tidak menampilkan nilai Dual Price serta ada pilihan apakah perlu ditampilkan nilai peubah keputusan yang nol.

2) Solve-Compile Model, digunakan untuk mengecek apakah struktur penyusunan data pada papan editor data sudah benar. Jika penulisannya tidak benar, maka akan ditampilkan pada baris ke-berapa kesalahan tersebut terdapat. Jika tidak ada kesalahan, maka proses dapat dilanjutkan untuk mencari jawaban yang optimal.

3) Solve Privot, digunakan untuk menampilkan nilai slack.

4) Solve Debug, digunakan untuk mempersempit permasalahan serta mencari pada bagian mana yang mengakibatkan solusi tidak optimal, selanjudnya ada pertanyaan untuk menentukan tingkat kesensitifitasan solusi. 


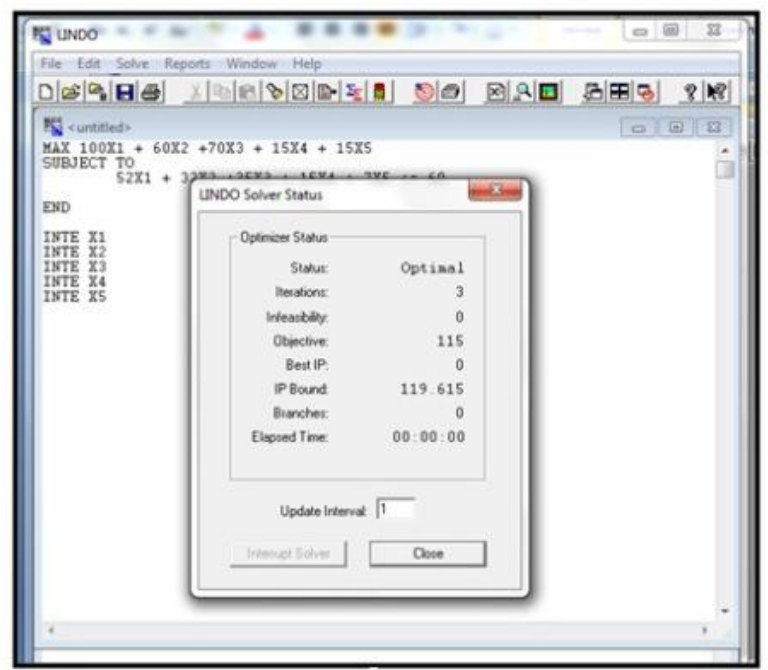

Gambar 5. Status Lindo Software

Jika tidak terjadi kesalahan akan muncul status Lindo. Satatus ini berguna untuk memonitor proses solusi. Selanjutnya tekan close dan pada Lindo akan muncul tampilan baru yang disebut report windows. Dalam report ini adalah 115 dengan $x 1$ $=\mathrm{x} 5=1$ dan $\mathrm{x} 2=\mathrm{x} 3=\mathrm{x} 4=0$.

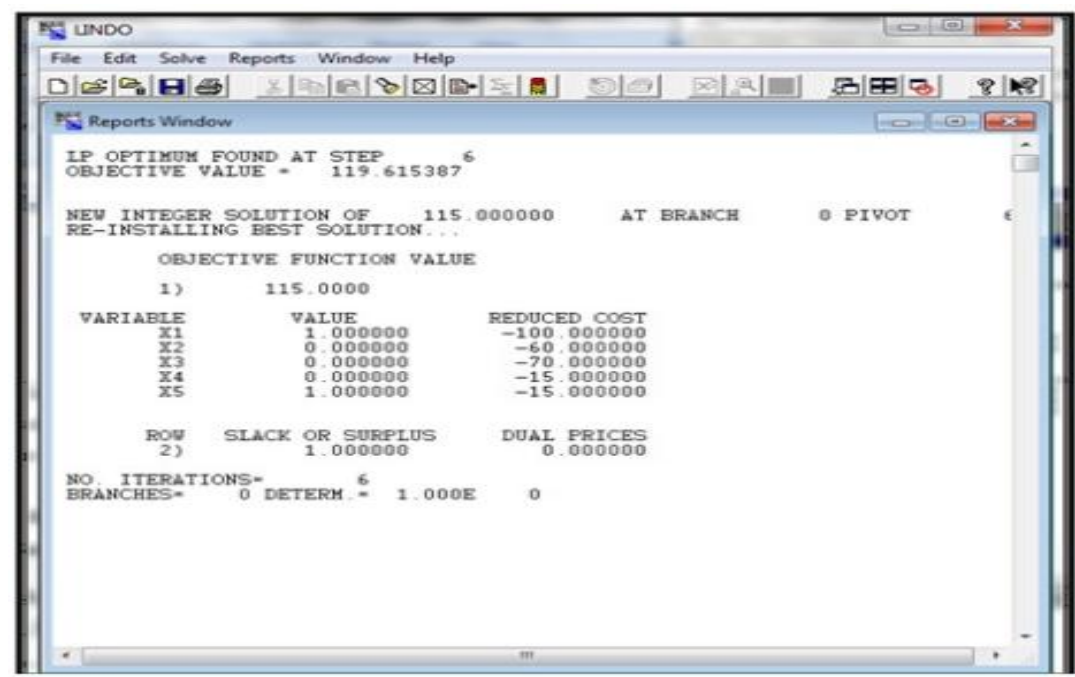

Gambar 6. Report Windows

\section{e. Menu Report}

Untuk tampilan pada report diatur sesuai dengan kebutuhan. Pengaturan report dilakukan dengan memilih Report pada toolbar Lindo. 


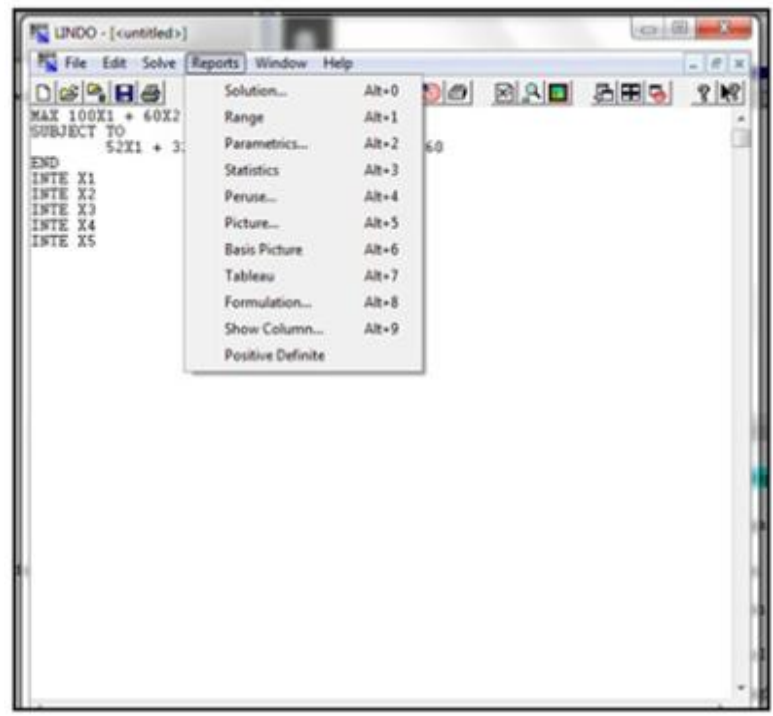

Gambar 7. Menu Report

Dalam menu report terdapat beberapa pilihan sebagai berikut:

1) Report Solution, digunakan untuk mendapatkan solusi optimal dari permasalahan program linier yang tersaji pada papan editor data.

2) Report Range, digunakan untuk menayangkan hasil penyelesaian analisis sensivitas. Pada analisis sensivitas yang ditayangkan mencakup aspek Allowable Increase dan Allowable Decrease.

3) Report Parametrics, digunakan untuk mengubah dan menampilkan hasil hanya pada baris kendala tertentu saja.

4) Report Statistics, digunakan untuk mendapatkan laporan kecil pada papan editor report.

5) Report Peruse, digunakan untuk menampilkan sebagian dari model atau jawaban.

6) Report Picture, digunakan untuk menampilkan (display) model dalam bentuk matriks.

7) Report Basis Picture, digunakan untuk menampilkan text format dari nilai basis, dan disajikan sesuai urutan baris dan kolom.

8) Report Table, digunakan untuk menampilkan tabel simplek dari model yang ada.

9) Report Formulation, digunakan untuk menampilkan model pada papan editor data ke papan editor report.

10) Report Show Coloum, digunakan untuk menampilkan koefisien peubah.

Untuk menyimpan file, arahkan kursor pada papan editor yang diaktifkan. Menu menyimpan file ada dua macam yakni File Save, dan File Save As. 


\subsection{Rancangan Contoh Bahan Ajar Mata Kuliah Program Linear pada Materi Simpleks Berbantu Lindo Software}

(Jabar, 2011:2) mengungkapkan Program Linier merupakan metode matematik dalam mengalokasikan sumberdaya yang langka untuk mencapai tujuan tunggal seperti memaksimumkan keuntungan atau meminimumkan biaya. Program Linier banyak diterapkan dalam membantu menyelesaikan masalah ekonomi, indutri, militer, sosial dan lain-lain. Permasalahan dalam program linier adalah permasalahan yang berhubungan dengan pencapaian fungsi sasaran atau masalah optimasi, yaitu yang bertujuan memecahkan masalah dengan cara terbaik, sesuai dengan prinsip ekonomi yang berorientasikan untuk senantiasa menekan (meminimalkan) pengeluaran untuk mendapatkan hasil yang maksimal.

Lindo adalah software yang digunakan untuk menyelesaikan masalah program linier dengan $\mathrm{n}$ variabel. Dengan Lindo penyelesaian permasalahan optimasi akan diperoleh secara cepat dan tepat, serta tingkat kesalahannya kecil. Jika hanya menggunakan program linier secara manual atau dengan menggunakan metode simpleks akan lebih sulit dan memakan waktu lebih lama karena membutuhkan ketelitian dan ketekunan yang tinggi. Untuk itu sangatlah tepat jika masalah dalam program linier seperti di atas ataupun segala permasalahan optimasi dalam dunia nyata di cari penyelesaiannya dengan Lindo.

Salah satu teknik penentuan solusi optimal yang digunakan dalam pemrograman linier adalah metode simpleks. Penentuan solusi optimal menggunakan metode simpleks didasarkan pada teknik eleminasi Gauss Jordan. Penentuan solusi optimal dilakukan dengan memeriksa titik ekstrim satu per satu dengan cara perhitungan iteratif. Sehingga penentuan solusi optimal dengan simpleks dilakukan tahap demi tahap yang disebut dengan iterasi. Iterasi ke-i hanya tergantung dari iterasi sebelumnya (i-1).

Susanta (1994:68) menyatakan bahwa masalah program linear dengan dua atau tiga peubah yang dapat disusutkan masih dapat diselesaikan dengan metode grafik. Untuk masalah program linear yang memuat tiga atau lebih peubah dan tidak dapat disusutkan menjadi masalah dengan dua peubah, maka harus menggunakan metode aljabar yang disebut metode simpleks.

\section{Rancangan Satuan Ajar Perkuliahan (SAP) Program Linear pada Materi Metode Simpleks}

a. Pandang:

a.1. Jurusan/Program Studi

b.1. Mata Kuliah

c.1. Satuan Kredit Semester (SKS)

d.1. Semester

: Pendidikan Matematika

: Program Linier

: 2 SKS

: VI (enam) 


\section{b. Dosen Pengampu}

\section{b.1. Koordinator}

c. Tujuan:

Mahasiswa dapat memformulasikan masalah-masalah pengambilan keputusan yang standar dari masalah optimasi linear serta dapat menyelesaikan dengan metode pengambilan keputusan secara kuantitatif

\section{d. Deskripsi Mata Kuliah}

Formulasi model-model optimasi: pendahuluan, formulasi aljabar secara umum, bentuk kanonik dari model optimasilinier, metode simpleks: perpindahan basis, sifat-sifat solusi optimum, solusi optimum yang fisibel, algoritma simpleks

e. Prasyarat : telah mengambil mata kuliah Aljabar Linear

\section{f. Indikator}

f.1. Dapat membuat membuat bentuk simpleks dengan memajukan penyelesaian layak basis (PLB).

f.2. Dapat menyelesaikan soal tak layak dengan kendala berlebih.

f.3. Dapat menyelesaikan metode simpleks dua tahap.

\section{g. Uraian Materi}

\section{g.1. Teori Simpleks}

g.2. Memajukan PLB

g.3. Menyusun Penyelesaian Basis Awal

g.4. Soal tak layak dan kendala berlebih

g.5. Metode Simpleks Dua Tahap

\section{h. Sumber Belajar}

M.S.Bazaraa. 1977. Linear Programming and Network Flaws. New York. John Wiley.

Marga .M. 1981. Matriks dan Perencanaaan Linier. Armico. Bandung.

J. Supranto, M.A. 1983. Linear Programming. Edisi Kedua. Lembaga Penerbit FE UI

Nasendi. B. D dan Anwar Alfendi. 1985. Program Linier \& Variansinya. Gramedia, Jakarta

B. Susanta. 1996. Program Linier. Depdikbud. Dirjen Dikti. 
Rancangan Materi Ajar Program Linear pada Materi Metode Simpleks Berbantua Lindo Software.

\section{a. Tujuan:}

Mahasiswa dapat memformulasikan masalah-masalah pengambilan keputusan yang standar dari masalah optimasi linear serta dapat menyelesaikan dengan metode pengambilan keputusan secara kuantitatif

\section{b. Materi Ajar}

Langkah-langkah yang perlu diperhatikan dalam metode simpleks, antara lain:

- Menyusun tablo awal dengan matriks $a_{i j}$ tersusun Gauss-Jordan $b_{i} \geq 0$

- Menguji keoptimuman tablo penyelesaian layak basis (PLB) bila sudah optimum berarti selesai, bila belum optimum lanjutkan kelangkah 3 .

- Memperbaiki tablo. Artinya, memilih peubah baru yang masuk menjadi basis dan memilih peubah lama yang keluar dari basis (diganti). Selanjutnya kembali kelangkah dua sampai ada penyelesaian optimum.

\begin{tabular}{|c|c|c|c|c|c|c|c|}
\hline & $\mathrm{C}_{\mathrm{j}}$ & $\mathrm{C}_{1}$ & $\mathrm{C}_{2}$ & $\ldots$ & $\mathrm{C}_{\mathrm{n}}$ & & \\
\hline & \begin{tabular}{l|l}
$X_{i}$ & $X_{j}$
\end{tabular} & $\mathrm{X}_{1}$ & $\mathrm{X}_{2}$ & $\ldots$ & $X_{n}$ & $b_{i}$ & $\mathrm{R}_{\mathrm{i}}$ \\
\hline $\mathrm{C}_{1}$ & $\mathrm{x}_{1}$ & $a_{11}$ & $a_{12}$ & $\ldots$ & $a_{1 n}$ & $b_{1}$ & $\mathrm{R}_{1}$ \\
\hline $\mathrm{C}_{2}$ & $\mathrm{x}_{2}$ & $\mathrm{a}_{21}$ & $\mathrm{a}_{12}$ & $\ldots$ & $\mathrm{a}_{11}$ & $\mathrm{~b}_{2}$ & $\mathrm{R}_{2}$ \\
\hline \multirow[t]{3}{*}{$\mathrm{C}_{\mathrm{n}}$} & $X_{m}$ & $\mathrm{a}_{\mathrm{m} 1}$ & $\mathrm{a}_{\mathrm{m} 2}$ & & $a_{m n}$ & $b_{m}$ & $\mathrm{R}_{\mathrm{m}}$ \\
\hline & $\mathrm{Zj}$ & $\mathrm{z}_{1}$ & $\mathrm{z}_{2}$ & $\ldots$ & $z_{n}$ & $\mathrm{Z}$ & \\
\hline & $\mathrm{Zj}-\mathrm{Cj}$ & $\mathrm{z}_{1}-\mathrm{c}_{1}$ & $\mathrm{Z}_{2}-\mathrm{c}_{2}$ & $\ldots$ & $\mathrm{z}_{\mathrm{n}}-\mathrm{c}_{\mathrm{n}}$ & $\mathrm{Z}$ & \\
\hline
\end{tabular}

Keterangan:

$\mathrm{X}_{\mathrm{i}} \quad$ : Peubah-peubah lengkap

$\mathrm{A}_{\mathrm{ij}} \quad$ : Koefisien Teknis

$\mathrm{b}_{\mathrm{i}} \quad$ : Suku Tetap

cj : Koefisien ongkos

$\mathrm{zj} \quad: \sum c i . a i j$

$\mathrm{Z} \quad: \sum c i . b i$

$\mathrm{Zj}-\mathrm{Cj} \quad$ : Selisih $\mathrm{Zj}$ dengan $\mathrm{Cj}$

$R i=\frac{b i}{\text { nilai kolom kunci }}$ 


\section{c. Contoh}

\section{METODE SIMPLEX (MAXIMISASI)}

Metode simplex merupakan suatu teknik pemecahan yang umum. Dalam metode simplex, model diubah ke dalam suatu bentuk tabel, kemudian diadakan suatu langkah matematis pada tabel tersebut.

Langkah-langkah matematis ini pada dasarnya merupakan replikasi proses pemindahan dari suatu titik ekstrim ke titik ekstrim lainnya pada batas daerah solusi (salution boundary). Metode simplex bergerak dari satu solusi ke solusi yang lebih baik sampai solusi yang terbaik didapat.

Program linier terdiri dari komponen dan karakteristik tertentu, kompones model adalah :

1. Variabel keputusan

Adalah simbol matematik yang menggambarkan tingkatan aktifitas perusahaan.

2. Fungsi tujuan

Adalah hubungan matematik linier yang menjelaskan tujuan perusahaan dalam terminologi variabel keputusan. Fungsi tujuan mempunyai salah satu target yaitu memaksimumkan atau meminimumkan suatu nilai.

3. Batasan model

Adalah hubungan linier dari antara variabel-variabel keputusan, batasan-batasan menunjukkan keterbatasan perusahaan karena lingkungan operasi perusahaan.

Misalnya akan dikerjakan contoh sebagai berikut dengan menggunakan metode simplex :

Maksimum Z $2 X_{1}+X_{2}+3 X_{3}$

$\mathrm{X}_{1}+\mathrm{X}_{2}+2 \mathrm{X}_{3} \leq 400$

$2 X_{1}+X_{2}+X_{3} \leq 500$

$\mathrm{X}_{1}, \mathrm{X}_{2}, \mathrm{X}_{3} \leq 0$

Dari contoh di atas dapat dengan mudah diselesaikan dengan menggunakan LINDO, caranya adalah sebagai berikut :

- Pastikan program Lindo telah siap

- Kemudian ketiklah persoalan di atas, seperti tampilan berikut ini : 


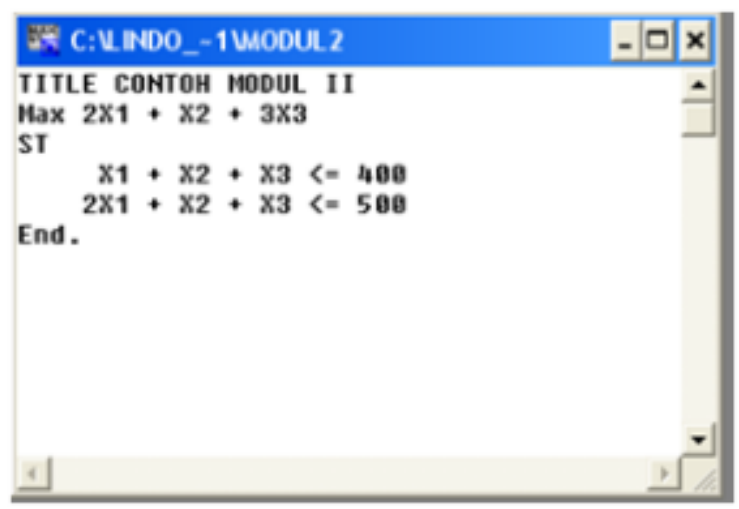

- Jika pengisian telah selesai, untuk mengetahui hasilnya dengn memilih menu Solve dan sub menu Solve, maka akan muncul pertanyaan berikut :

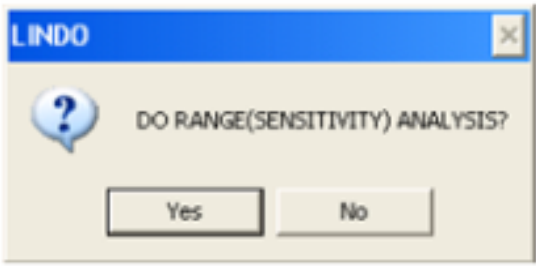

- Jawablah Yes, maka akan muncul hasil akhir seperti berikut :

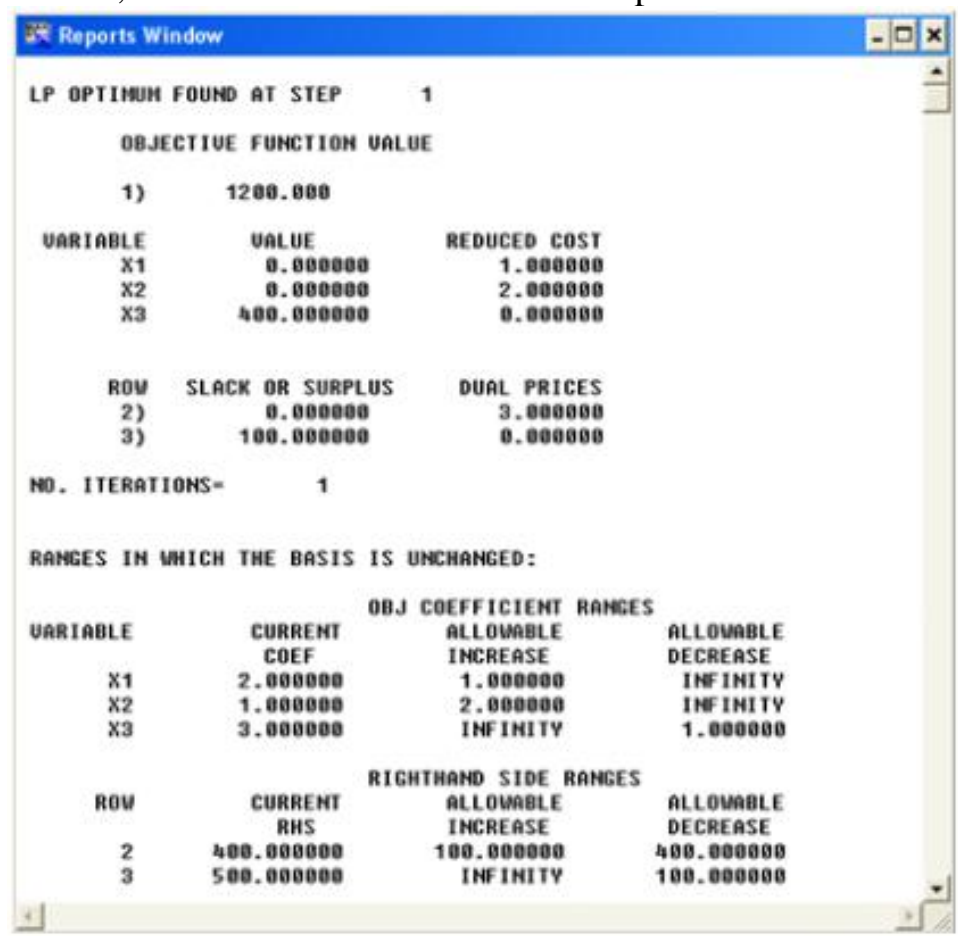


Dari rincian hasil di atas ditafsirkan bahwa total maksimum adalah 1200. Dengan $X_{1}$ $=X_{2}=0$ dan $X_{3}=400$.

\section{METODE SIMPLEX (MINIMISASI)}

Secara umum langkah-langkah metode simplex telah dijabar pada Metode Simpleks Maksimasi, tetapi untuk masalah minimisasi diperlukan sedikit perubahan dalam proses simplex yang normal. Ini meliputi masalah batasan-batasan campuran, masalah solusi majemuk, tidak ada solusi yang fisibel atau solusi yang tak berbatas, masalah dengan kolom pemutar, masalah dengan baris pemutar dan masalah dengan nilai kuantitas batasan yang negatif.

Tidak satupun dari masalah tersebut yang memerlukan perubahan dalam metode simplex. Pada dasarnya masalah-masalah tersebut merupakan hasil yang tidak biasa dalam tabel simplex dimana sebaiknya kita mengetahui bagaimana menginterprestasikannya.

Misalnya akan dikerjakan contoh sebagai berikut dengan menggunakan metode simplex :

Meminimumkan $Z=100 \mathrm{x}_{1}+100 \mathrm{x}_{2}+100 \mathrm{x}_{3}$

$2 X_{1}+2 X_{2}+X_{3} \leq 22$

$2 \mathrm{X}_{1}+\mathrm{X}_{2}+2 \mathrm{X}_{3} \geq 30$

$$
X_{2}+2 X_{3} \geq 25
$$

$\mathrm{X}_{1}, \mathrm{X}_{2}, \mathrm{X}_{3} \geq 0$

Dari contoh di atas dapat dengan mudah diselesaikan dengan menggunakan LINDO For Windows, caranya adalah sebagai berikut :

- Pastikan program LINDO siap

- Kemudian ketiklah persoalan di atas, seperti tampilan berikut ini :

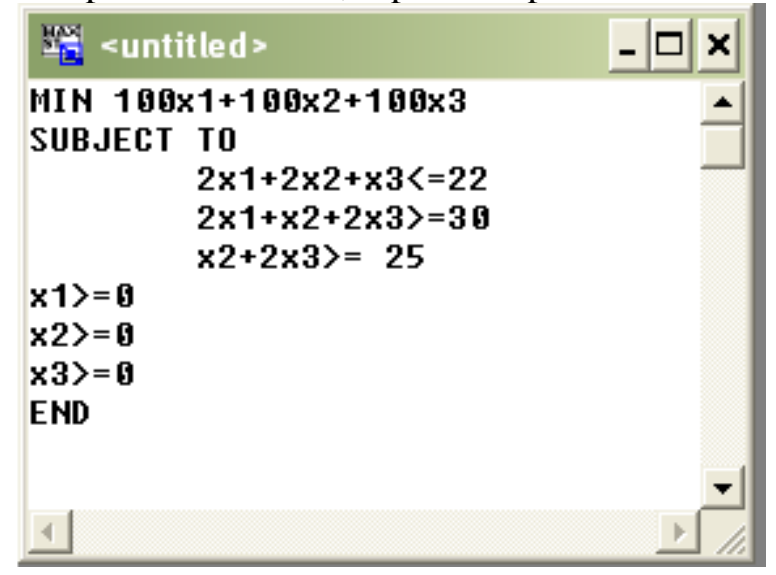


- Jika pengisian telah selesai, untuk mengetahui hasilnya dengn memilih menu Solve dan sub menu Solve, maka akan muncul pertanyaan berikut :

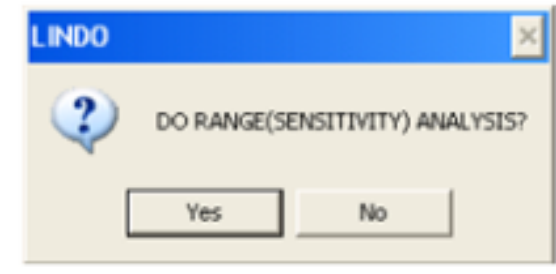

- Jawablah Yes, maka akan muncul hasil akhir seperti berikut :

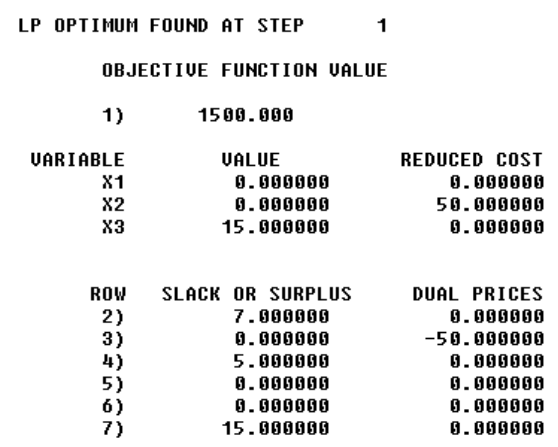

NO. ITERATIONS $=1$

RANGES IN WHICH THE BASIS IS UNCHANGED :

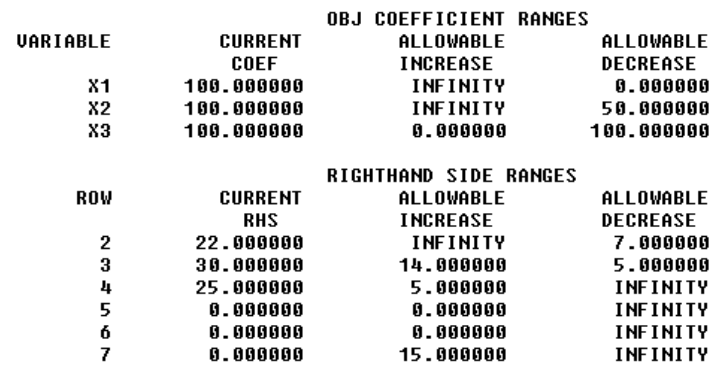

Dari rincian hasil di atas ditafsirkan bahwa total minimum adalah 1500 .

Dengan $X_{1}=X_{2}=0$ dan $X_{3}=15$.

\section{d. Evaluasi}

Selesaikan linear program berikut ini dengan metode Simplex

1). Maksimumkan $Z=2 X_{1}+3 X_{2}+X_{3}$

Dengan fungsi kendala:

$$
\begin{aligned}
X_{1}+X_{2}+X_{3} & \leq 9 \\
2 X_{1}+3 X_{2} & \leq 25 \\
X_{2}+2 X_{3} & \leq 10 \\
X_{1}, X_{2}, X_{3} \geq 0 &
\end{aligned}
$$


2). Minimumkan $Z=3 X_{1}+2 X_{2}$

Fungsi batasan :

$\mathrm{X} 1+2 \mathrm{X} 2 \geq 20$

$3 \mathrm{X} 1+\mathrm{X} 2 \geq 20$

$\mathrm{X} 1 \geq 0, \mathrm{X} 2 \geq 0$

\section{METODE PENELITIAN}

Metode penelitian yang digunakan adalah metode penelitian kuantitatif. Desain penelitian yang digunakan adalah Pretest-Posttest Control Group Design. Populasi penelitian adalah seluruh mahasiswa semester III Prodi Pendidikan Matematika Universitas Almuslim. Pengambilan sampel dalam penelitian ini dilakukan dengan menggunakan teknik purposive sampling. Teknik purposive sampling adalah teknik penentuan sampel dengan pertimbangan tertentu (Sugiyono, 2010). Sampel dalam penelitian ini adalah satu kelompok mahasiswa unit A semester III Prodi Pendidikan Matematika Universitas Almuslim. Data dalam penelitian ini diperoleh dari instrumen yang digunakan yaitu instrumen yang disusun dalam bentuk tes yang dijawab oleh responden secara tertulis. Instrumen, yaitu: tes (awal dan akhir). Teknik analisis data yang dilakukan adalah analisis inferensial yang digunakan untuk mendeskripsikan dan mengambil kesimpulan dari data yang telah terkumpul.

Program yang dilaksanakan meliputi:

a. Pemilihan materi perkuliahan

Para dosen pengampu mempunyai beberapa pertimbangan yang dipilih berbagai topik yang layak dengan model perkuliahan yang baru pada perkuliahan program linear.

b. Persiapan dosen

Sebelum perkuliahan dilaksanakan di semester ganjil 2013/2014, dosen sudah mempersiapkan bahan ajar, serta perlengkapan yang akan digunakan dalam proses pembelajaran dengan berbantuan Lindo Software.

c. Pelaksanaan pembelajaran dan pengembangan media

Pembelajaran program linear dengan berbantu Lindo Software turut diikuti oleh tim dosen lainnya sebagai aggota tim, guna untuk memberikan masukan serta arahan dalam perbaikan proses pembelajaran. Bagan desain program dapat digambarkan sebagai berikut: 


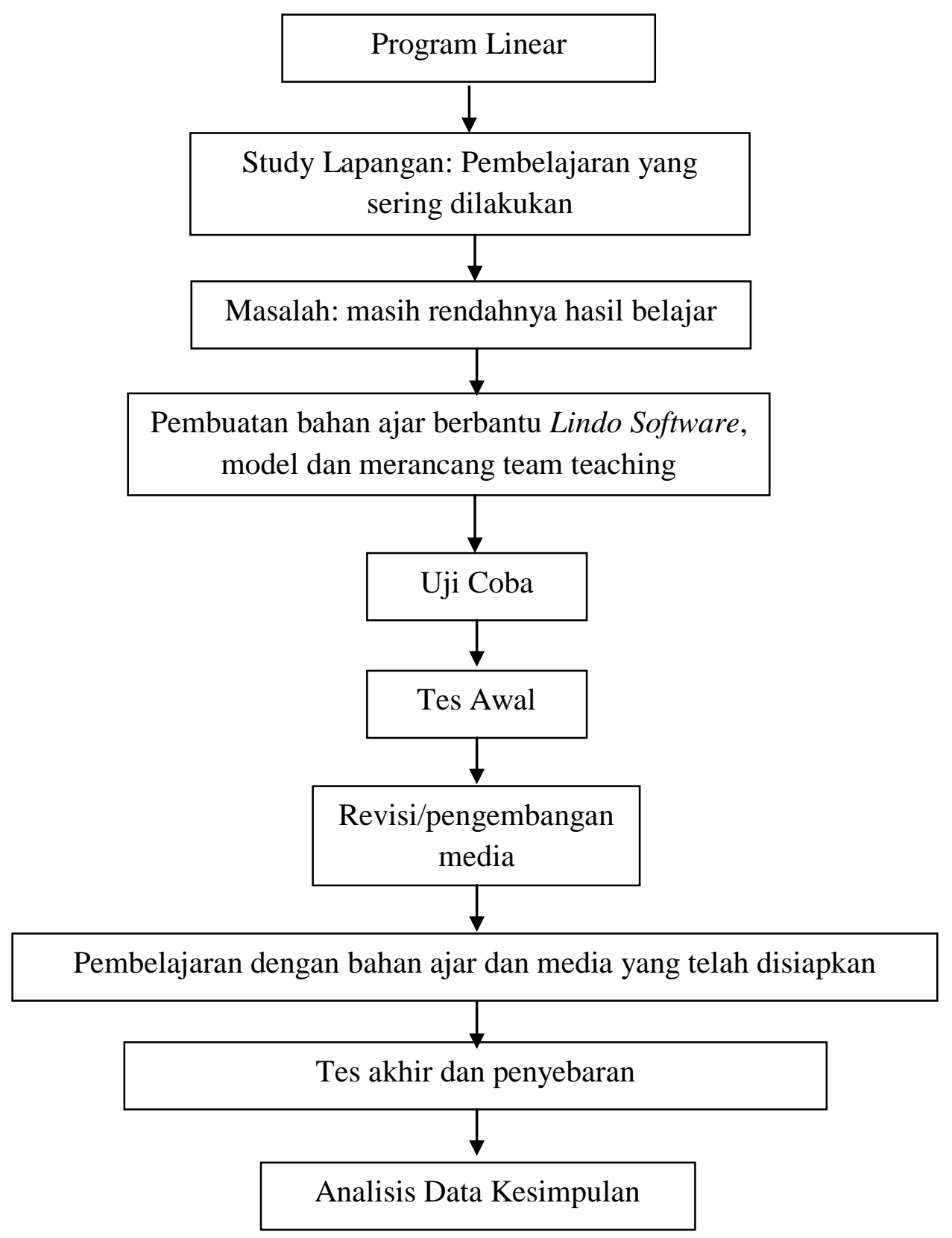

Bagan 3.1 Desain Penelitian 


\section{Indikator Kinerja}

Adapun indikator kinerja yang menjadi acuan penulis dalam perbaikan dan pengembangan media Lindo Software dalam penggunaannya pada mahasiswa semester III Prodi Pendidikan Matematika Universitas Almuslim tahun ajaran 2013/2014 adalah sebagai berikut:

1. Peningkatan hasil belajar mata kuliah program linear yang lebih baik, guna untuk meningkatkan SDM yang lebih baik.

2. Pengorganisasian kelas yang terkontrol. Hal ini dapat dilihat dari besarnya minat mahasiswa dalam mengikuti perkuliahan hingga selesai.

3. Pengembangan kreativitas dosen dalam kinerja pembelajaran yang lebih baik

\section{HASIL DAN PEMBAHASAN}

Pembahasan hasil penelitian ini berdasarkan pada faktor-faktor yang diamati dan ditemukan dalam penelitian.

\section{Pencapaian Kemampuan Awal Mahasiswa}

Tabel 4.1 Deskripsi Data Pretest Kelas Eksperimen dan Kontrol

\begin{tabular}{|c|c|c|c|c|c|c|c|c|}
\hline $\begin{array}{c}\text { Kela } \\
\text { S }\end{array}$ & \multicolumn{4}{|c|}{ Kelompok Eksperimen } & \multicolumn{4}{c|}{ Kelompok Kontrol } \\
\hline $\mathbf{N}$ & $\begin{array}{c}\text { Rata- } \\
\text { rata }\end{array}$ & $\mathbf{X}_{\text {Min }}$ & $\mathbf{X}_{\text {Maks }}$ & $\begin{array}{c}\text { Simpangan } \\
\text { Baku }\end{array}$ & $\begin{array}{c}\text { Rata- } \\
\text { rata }\end{array}$ & $\mathbf{X}_{\text {Min }}$ & $\mathbf{X}_{\text {Maks }}$ & $\begin{array}{c}\text { Simpangan } \\
\text { Baku }\end{array}$ \\
\hline 30 & 44.33 & 10.00 & 80,00 & 20.66 & 36.00 & 70,00 & 4,00 & 19.80 \\
\hline
\end{tabular}

Berdasarkan Tabel 4.1 di atas, dapat dilihat bahwa rata-rata skor kemampuan awal untuk kelompok yang akan mendapat pembelajaran (kelas eksperimen) lebih besar daripada kelompok mahasiswa pada kelas kontrol dengan pembelajaran konvensional, untuk aspek komunikasi matematis.

\section{Pencapaian Kemampuan Akhir Mahasiswa}

Tabel 4.2 Deskripsi Data Posttest Kelas Eksperimen dan Kontrol

\begin{tabular}{|c|c|c|c|c|c|c|c|c|}
\hline Kelas & \multicolumn{4}{|c|}{ Kelompok Eksperimen } & \multicolumn{4}{c|}{ Kelompok Kontrol } \\
\hline $\mathbf{N}$ & $\begin{array}{c}\text { Rata- } \\
\text { rata }\end{array}$ & $\mathbf{X}_{\text {Min }}$ & $\mathbf{X}_{\text {Maks }}$ & $\begin{array}{c}\text { Simpangan } \\
\text { Baku }\end{array}$ & $\begin{array}{c}\text { Rata- } \\
\text { rata }\end{array}$ & $\mathbf{X}_{\text {Min }}$ & $\mathbf{X}_{\text {Maks }}$ & $\begin{array}{c}\text { Simpangan } \\
\text { Baku }\end{array}$ \\
\hline 30 & 79.33 & 60.00 & 100,0 & 14.36 & 65.00 & 40,00 & 90,0 & 17.46 \\
\hline
\end{tabular}

Berdasarkan Tabel 4.2 di atas, dapat dilihat bahwa rata-rata skor kemampuan akhir untuk kelompok yang akan mendapat pembelajaran (kelas eksperimen) lebih besar daripada kelompok mahasiswa pada kelas kontrol dengan pembelajaran 
konvensional. Sedangkan penyebaran data untuk kelas kontrol lebih tinggi daripada kelas eksperimen.

\section{Uji Kesamaan Rata-rata}

Setelah melakukan uji normalitas dan uji homogenitas maka dilanjutkan dengan uji kesamaan rata-rata. Perhitungannya menggunakan SPSS 16 pada taraf signifikansi $\alpha=0,05$. Kriteria pengujian adalah tolak $\mathrm{H}_{0}$ jika Asymp.Sig.(1-tailed) $<\alpha=0,05$. Hasil uji kesamaan rata-rata dapat dilihat pada rangkuman hasil perhitungan yang ditunjukkan pada tabel di bawah ini.

Tabel 4.3

Uji Kesamaan Rata-rata

\begin{tabular}{|c|c|c|l|c|}
\hline Kelas & df & $\begin{array}{c}\text { Asymp.Sig. } \\
\text { (2-tailed) }\end{array}$ & Kesimpulan & Keterangan \\
\hline Eksperimen & $\mathbf{5 8}$ & $\mathbf{0 , 1 1 6}$ & $\mathbf{H}_{0}$ diterima & $\begin{array}{c}\text { Tidak } \\
\text { Terdapat } \\
\text { Perbedaan }\end{array}$ \\
\hline Kontrol & $\mathbf{5 8}$ & &
\end{tabular}

Dari Tabel 4.3, untuk $\alpha=0,05, \mathrm{t}_{(1-\alpha)} \mathrm{dk}=58$ dan uji-t satu sampel independent maka signifikansi adalah 0,116. Karena Asymp.sig $=0,116>0,05=\alpha$, maka $_{0}$ diterima, sehingga $\mathrm{H}_{1}$ ditolak. Ini memberi kesimpulan bahwa tidak terdapat perbedaan hasil belajar mahasiswa.

\section{Uji Perbedaan Rata-rata}

Setelah melakukan uji normalitas dan uji homogenitas maka dilanjutkan dengan uji perbedaan rata-rata. Perhitungannya menggunakan SPSS 16 pada taraf signifikansi $\alpha=0,05$. Kriteria pengujian adalah tolak $\mathrm{H}_{0}$ jika Asymp.Sig.(1-tailed) $<\alpha=0,05$. Hasil uji perbedaan rata-rata dapat dilihat pada rangkuman hasil perhitungan yang ditunjukkan pada tabel di bawah ini.

Tabel 4.4

Uji Perbedaan Rata-rata Kemampuan Komunikasi Matematis

\begin{tabular}{|c|c|c|c|c|}
\hline Kelas & df & $\begin{array}{c}\text { Asymp.Sig. } \\
\text { (2-tailed) }\end{array}$ & Kesimpulan & Keterangan \\
\hline Eksperimen & $\mathbf{5 8}$ & $\mathbf{0 , 0 0 1}$ & $\mathbf{H}_{\mathbf{0}}$ ditolak & $\begin{array}{c}\text { Terdapat } \\
\text { Perbedaan }\end{array}$ \\
\hline Kontrol & $\mathbf{5 8}$ &
\end{tabular}

\section{KESIMPULAN DAN SARAN}

Berdasarkan hasil penelitian dan pembahasan mengenai pengembangan bahan ajar program linear berbantuan lindo software, maka diperoleh kesimpulan sebagai berikut: 
(1) Terdapat perbedaan hasil belajar mahasiswa yang mendapatkan pembelajaran berbantuan lindo software daripada mahasiswa yang mendapat pembelajaran konvensional;

(2) Untuk menentukan bentuk umum model matematika adalah sebagai berikut:

Fungsi tujuan :

Maksimumkan atau minimumkan $\mathrm{z}=\mathrm{c} 1 \mathrm{x} 1+\mathrm{c} 2 \mathrm{x} 2+\ldots+\mathrm{cn} \times \mathrm{n}$

Sumber daya yang membatasi :

$$
\begin{aligned}
& \mathrm{a} 11 \mathrm{x} 1+\mathrm{a} 12 \times 2+\ldots+\mathrm{a} 1 \mathrm{nxn}=/ \leq / \geq \mathrm{b} 1 \\
& \mathrm{a} 21 \mathrm{x} 1+\mathrm{a} 22 \mathrm{x} 2+\ldots+\mathrm{a} 2 \mathrm{nxn}=/ \leq / \geq \mathrm{b} 2 \\
& \ldots \ldots \ldots \ldots \ldots \\
& \text { am } 1 \mathrm{x} 1+\mathrm{am} 2 \mathrm{x} 2+\ldots+\mathrm{amnxn}=/ \leq / \geq \mathrm{bm} \\
& \mathrm{x} 1, \mathrm{x} 2, \ldots, \mathrm{xn} \geq 0
\end{aligned}
$$

Untuk membuat bentuk formulasi permasalahan optimasi dengan Lindo adalah sebagai berikut.

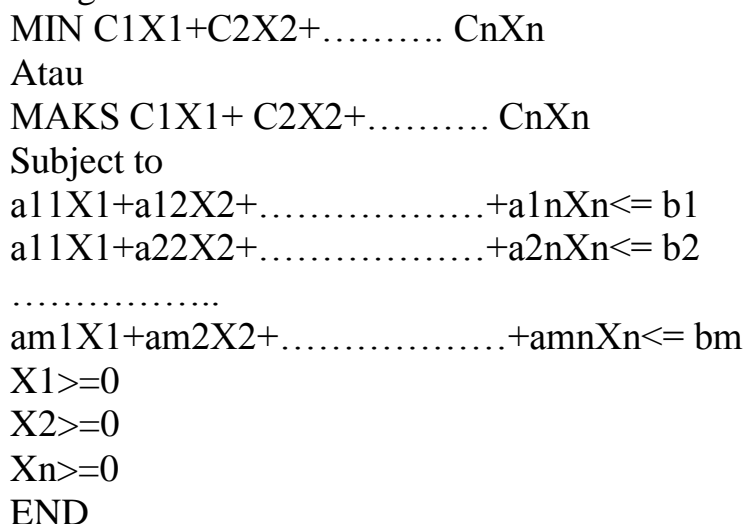

Saran pada penelitian ini agar dapat lebih memahami bagaimana cara mengoperasikan lindo software untuk menyelesaikan masalah optimasi dalam program linier sebaiknya diadakan penelitian lanjut.

\section{DAFTAR PUSTAKA}

Atini, Murni. (2013). TUTORIAL LINDO (Linear Ineraktive Discrete Optimizer). [online]. Tersedia: http://murniiatiinii.wordpress.com/2013/01/08/tutoriallindo-linear-ineraktive-discrete-optimizer/ [25 agustus 2013]

Chairani, Yuni. (2011). Pembelajaran Matematika Dengan Software Geogebra Untuk Meningkatkan Kemampuan Pemahaman Konsep Siswa Dengan Model Pembelajaran Ekslorasi. Makalah UPI Bandung: Tidak diterbitkan 
Hermanto, Teguh. (2010). Menyelesaikan Masalah Optimasi dalam Program Linier dengan Lindo. [online]. Tersedia: http://id.scribd.com/doc/34179882/MENYELESAIKAN-MASALAHOPTIMASI [25 agustus 2013]

Kabar, Abdul. (2011). Diktat Program Linear. Banjarmasin: STKIP PGRI Banjarmasin

Mulyasa, E. (2008). Menjadi Guru Profesional. Bandung: Rosda

Purnomo, Djoko. (2011). Pengembangan Bahan Ajar Matematika Sebagai Sarana Pengembangan Kreativitas Berpikir. Makalah Jurusan Pendidikan Matematika FPMIPA IKIP PGRI Semarang

Rusmini. (2007). Meningkatkan kemampuan penalaran dan komunikasi matematis siswa smp melalui pendekatan pembelajaran kontekstual berbantuan Program cabri geometri. Tesis PPS UPI Bandung: Tidak diterbitkan.

Sugiyono. (2010). Metode Penelitian Kuantitatif Kualitatif dan $R \&$ D. Bandung: CV Alfabeta.

Suherman, E. dkk. (2003). "Common Text Book” dalam Strategi Pembelajaran Matematika Kontemporer. Bandung. JICA UPI

Sumarmo, U. (2006). Pembelajaran Keterampilan Membaca Matematika Pada Siswa Sekolah Menengah. FPMIPA UPI Bandung

Susanta, B. (1994). Program Linear. Jakarta. DEPDIKBUD

TIMSS, (2003). International Students Achievement In Mathematics. [Online]. Tersedia: http://timss:bc.edu/timss2003i/pdf/T03imath01.pdf [25 agustus 2013]

Undang-undang R.I. No 23 (2003), Tentang Sistem Pendidikan Nasional Tahun 2003. Tersedia: http://dikti.go.id 